\title{
Genome Mining Reveals Secondary Metabolites of Antarctic Bacterium Streptomyces Albidoflavus ANT_B131 Related to Antimicrobial and Antiproliferative Activities
}

\section{Paula de França ( $\sim$ pauladfranca@gmail.com )}

Microbial Resourses Division, Research Center for Chemistry, Biology and Agriculture (CPQBA), University of Campinas (UNICAMP), Campinas, SP

\section{Jonas Costa}

Institute of Chemistry (IQ), University of Campinas (UNICAMP), CP 6154, 13083-970, Campinas, SP

\section{Taícia Fill}

Institute of Chemistry (IQ), University of Campinas (UNICAMP), CP 6154, 13083-970, Campinas, SP Marcelo Lancelotti

Faculty of Pharmaceutical Sciences, University of Campinas (UNICAMP), Campinas, SP

Ana Ruiz

Faculty of Pharmaceutical Sciences, University of Campinas (UNICAMP), Campinas, SP

\section{Fabiana Fantinatti-Garboggini}

Microbial Resourses Division, Research Center for Chemistry, Biology and Agriculture (CPQBA), University of Campinas (UNICAMP), Campinas, SP

\section{Research Article}

Keywords: Streptomyces albidoflavus, genome mining, secondary metabolites, Antarctica, marineassociated bacteria, polyketide, non-ribosomal peptide, antimicrobial activity, antiproliferative activity

Posted Date: December 15th, 2020

DOl: https://doi.org/10.21203/rs.3.rs-123886/v1

License: (c) (1) This work is licensed under a Creative Commons Attribution 4.0 International License. Read Full License 


\section{Abstract}

The antimicrobial resistance requires the urgent mining of new antimicrobials. Actinobacteria, specially Streptomyces genus, are responsible for production of numerous clinical antibiotics and anticancer agents. The use of genome mining can reveal the genetic potential of a strain to produce natural products, however the potential may not be express under laboratory conditions. In the present study, the Antarctic bacterium was taxonomically affiliated as Streptomyces albidoflavus, ANT_B131. The crude extracts showed antimicrobial activity against fungi, Gram-positive and Gram-negative bacteria and antiproliferative activity against five human tumor cell lines. Whole genome sequencing reveals a $6.96 \mathrm{Mb}$ genome size and the genome mining showed 24 BGCs, representing $13.3 \%$ of the genome. The use of three culture media and extraction methods reveal the expression and recovery of $20 \%$ of the BGCs. The natural products identified were surugamide A, surugamide D, desferrioxamine B + Al, desferrioxamine E, and ectoine. This study reveals the potential of S. albidoflavus ANT_B131 as a natural product producer. Yet, the diversity of culture media and extraction methods could enhance the BGCs expression and recovery of natural products, and could be a new strategy to intensify the BGC expression of natural products.

\section{Introduction}

In the past few years, Antarctica has been an important resource of new microbial natural products, to obtain antimicrobials, antiprotozoal, biosurfactants, enzymes, antitumor, antiviral, immunosuppressant, and antioxidant compounds ${ }^{1-6}$. The extreme environmental conditions provide a unique metabolic response for microorganisms ${ }^{7}$. The growth of antimicrobial resistance became urgent the searching for new compounds capable of confronting resistant pathogenic microorganisms ${ }^{8}$. Also, cancer is one of the most complex diseases and acts in different organs in the human organism. The high level of mortality and the specificity of the treatment leads to the urgent need for novel antiproliferative compounds ${ }^{9}$. In this context, the phylum Actinobacteria, of which the Streptomyces genus belongs, are responsible for $90 \%$ of the production of antibiotics ${ }^{10}$ and novel natural products.

The usual methodologies for the discovery of natural products lead to a high rate of rediscovery of the same molecules. The increase in the microbial genome sequencing, metabolomic analyses, and synthetic biology have improved the search and discovery of novel natural products from microorganisms in environments that are still little explored ${ }^{11,12}$. Furthermore, we aimed to perform the genome mining associated with a metabolomics approach of Antarctic Streptomyces albidoflavus ANT_B131, whose crude extracts showed antimicrobial and antiproliferative activity.

\section{Material And Methods}

\section{Streptomyces isolation.}


The tunicate, Salp sp., was collected in Punta Plaza, Admiralty Bay, King George Island, Antarctica during an expedition in the austral summer of 2010 by the Brazilian Antarctic Program team. The sample was ground in a homogenizer, serially diluted up $\left(10^{-2}\right.$ and $\left.10^{-4}\right)$ and plated on Petri dishes with the culture media. The bacterium was isolated on $\mathrm{M} 1$ medium (peptone $2 \mathrm{~g} \mathrm{I}^{-1}$, yeast extract $4 \mathrm{~g} \mathrm{I}^{-1}$, starch $10 \mathrm{~g} \mathrm{I}^{-1}$, and agar $18 \mathrm{~g} \mathrm{I}^{-1} ; \mathrm{pH} \mathrm{7.0)}$ prepared with artificial seawater, ASW, $\left(\mathrm{KBr} 0.1 \mathrm{~g} \mathrm{I}^{-1}, \mathrm{NaCl} 23.48 \mathrm{~g} \mathrm{I}^{-1}\right.$, $\mathrm{MgCl}_{2} \cdot 6 \mathrm{H}_{2} \mathrm{O} 10.61 \mathrm{~g} \mathrm{I}^{-1}, \mathrm{CaCl}_{2} \cdot 2 \mathrm{H}_{2} \mathrm{O} 1.47 \mathrm{~g} \mathrm{I}^{-1}, \mathrm{KCl} 0.66 \mathrm{~g} \mathrm{I}^{-1}, \mathrm{SrCl}_{2} \cdot 6 \mathrm{H}_{2} \mathrm{O} 0.04 \mathrm{~g} \mathrm{I}^{-1}, \mathrm{Na}_{2} \mathrm{SO}_{4} 3.92 \mathrm{~g} \mathrm{I}^{-1}$, $\left.\mathrm{NaHCO}_{3} 0.19 \mathrm{~g} \mathrm{I}^{-1}, \mathrm{H}_{3} \mathrm{BO}_{3} 0.03 \mathrm{~g} \mathrm{I}^{-1}\right)$ at $15^{\circ} \mathrm{C}$ and maintained by cryopreservation $\left(-80^{\circ} \mathrm{C}\right.$ in $20 \%$ glycerol).

\section{Phylogenetic analysis.}

The genomic DNA was extracted ${ }^{13}$ and PCR amplified the 16 S ribosomal RNA (Lane, 1991) and taken to sequencing in automated sequencer $A B I 3500 X L$ series (Applied Biosystems). The sequences were assembled ${ }^{14,15}$ in contigs of approximately 1100 bp and were subjected to comparison in the databases $^{16,17}$. The sequences retrieved from the databases were aligned in the CLUSTAL $X^{18}$, edited and analyzed phylogenetically using MEGA $X^{19}$. The evolutionary distance was calculated by Kimura model ${ }^{20}$ and the construction of a phylogenetic trees based on the evolutionary distances were made by the neighbor-joining method ${ }^{21}$ with bootstrap values calculated from 1,000 replications ${ }^{22}$.

\section{Crude extract production.}

Starter culture $(50 \mathrm{~mL})$ was used to scale toward larger volume cultures $(100 \mathrm{~mL}, 500 \mathrm{~mL})$ of Nutrient Broth (NB, Oxoid ${ }^{\mathrm{TM}}$ ) medium with ASW, and incubated at $28^{\circ} \mathrm{C}$ for 30 days under stationary conditions. The negative control was included in the production of crude extracts, and it represented the culture media without bacterial growth. After the incubation period, ethyl acetate was added to the liquid culture (1:1 ratio) and the medium and solvent were mixed in a homogenizer at 7,000 rpm for $6 \mathrm{~min}$. The extracts were obtained by liquid-liquid extraction method and, the organic phases were concentrated under vacuum in a Rotary evaporator (Buchi ${ }^{\circledR} \mathrm{R}-215$ ) at $40{ }^{\circ} \mathrm{C}$ and $80 \mathrm{rpm}$. The crude extracts were stored at -20 ${ }^{\circ} \mathrm{C}$ until their use in assays.

\section{Antimicrobial activity.}

The antimicrobial activity of crude extract was tested to determine the Minimum Inhibitory Concentration (MIC) and Minimum Bactericidal Concentration (MBC) by microdilution assay according to the Clinical \& Laboratory Standards Institute (CLSI) ${ }^{23-25}$. Crude extracts were solubilized in $2.5 \%$ of dimethyl sulfoxide and Muller-Hinton broth (BD Difco ${ }^{\top \mathrm{T}}$ ) and assayed from 0.0078 to $2.0 \mathrm{mg}^{\mathrm{mL}} \mathrm{m}^{-1}$. Bacterial extracts were tested against the strains of yeast Candida albicans ATCC 10231, Gram-positive and Gram-negative bacteria, that included virulent and pathogenic reference strains (Table 2). The Nalidixic acid was 
included as positive control. The crude extracts were incubated without the microorganism inoculation to verify any type of contamination, the viability of the cells was confirmed during the test, and the medium was used as negative control. The test was performed in triplicate.

\section{Antiproliferative activity.}

The antiproliferative activity was performed in an in vitro assay ${ }^{26}$ against a panel of human tumours glioblastoma (U251), mammalian adenocarcinoma (MCF-7), ovarian multi-drug resistant adenocarcinoma (NCl/ADR-RES), large cell carcinoma of lung (NCl-H460), adenocarcinoma of kidney (786-0), prostatic adenocarcinoma (PC-3), colon adenocarcinoma (HT-29), chronic myeloid leukemia (K562) and non-tumour (HaCat, immortalized keratinocytes) cell lines. The cells grew in complete medium, RPMI 1640 supplemented with $5 \%$ fetal bovine serum and $1 \%$ penicillin/streptomycin mixture $(1,000$ Ul: $\left.1,000 \mu \mathrm{g} \cdot \mathrm{mL}^{-1}\right)$, at $37^{\circ} \mathrm{C}$ and $5 \% \mathrm{CO}_{2}$ in a humidified atmosphere. Human tumour and the human nontumoural cell lines were provided by the Frederick Cancer Research \& Development Center (National Cancer Institute, Frederick, MD, USA), and Dr. Ricardo Della Colleta (University of Campinas). The extract was solubilized in dimethyl sulfoxide $\left(100 \mathrm{mg} \cdot \mathrm{mL}^{-1}\right)$ followed by serial dilution in complete medium affording the final concentrations $(0.25,2.5,25$ and $250 \mu \mathrm{g} / \mathrm{mL})$. Doxorubicin was diluted following the same protocol and used as a positive control at final concentrations of $0.025,0.25,2.5$ and $25 \mu \mathrm{g} \cdot \mathrm{mL}^{-1}$. The complete medium was used as negative control. The $\mathrm{GI}_{50}$ indicated the concentration $\left(\mu \mathrm{g} \cdot \mathrm{mL}^{-1}\right)$ to the crude extract reduce $50 \%$ of the cellular proliferation.

\section{Whole genome sequencing.}

Whole genome sequencing of the Streptomyces sp. ANT_B131 was performed to evaluate the encoded potential of secondary metabolites production related to biosynthetic gene clusters (BGCs) in this strain. The genomic DNA was performed with UltraClean Microbial DNA Extraction Kit (Mo Bio Laboratories, Carlsbad, USA). Paired-end libraries were prepared followed by $2 \times 251$ bp sequencing on Illumina HiSeq platform. The quality of the reads were determined using FastQC

(https://www.bioinformatics.babraham.ac.uk/projects/fastqc/) and filtered with Trimmomatic 3.027. The assembled was performed with SeqMan NGen version 14.0 software (DNASTAR, Inc., WI, USA) and the quality evaluated by Quast $4.0^{28}$. The contigs were realign using MAUVE ${ }^{29}$ and Streptomyces albidoflavus J1074 genome (accession number PRJNA180996) was used as reference genome. The genome was annotated by NCBI Prokaryotic Genome Annotation Pipeline (PGAP) ${ }^{30}$, and the Rapid Annotations using Subsystems Technology (RAST) ${ }^{31}$, PATRIC $^{32}$, and the completeness was performed by BuSCO $^{33}$.

\section{Multi-locus Sequence Analysis.}


The phylogenetic analysis of the Multi-locus Sequence Analysis (MLSA) were performed using five house-keeping genes: atpD (ATP synthase F1, beta subunit), gyrB (DNA gyrase B subunit), rpoB (RNA polymerase beta subunit), $\operatorname{rec} A$ (recombinase $A$ ), and $\operatorname{trp} B$ (tryptophan synthetase, beta subunit $A$ ) (See Supplementary Table 1), as recommended by Labeda et al. (2016). The Streptomyces sp. ANT_B131 genes were annotated by PATRIC ${ }^{32}$ and used in this study. The evolutionary history was inferred using the Neighbor-Joining method ${ }^{21}$. The percentage of replicate trees in which the associated taxa clustered together in the bootstrap test (1000 replicates) ${ }^{22}$. The evolutionary distances were computed using the Kimura 2-parameter method ${ }^{20}$ and are in the units of the number of base substitutions per site. The analysis involved 19 nucleotide sequences. All ambiguous positions were removed for each sequence pair. There were a total of 2525 positions in the final dataset. Evolutionary analyses were conducted in MEGA $X^{19}$.

\section{In silico DNA-DNA hybridization.}

The in silico DNA-DNA hybridization (isDDH), local alignment by BLAST + , and difference in $\% \mathrm{G}+\mathrm{C}$ content of genomes was calculated using Genome-to-Genome Distance Calculator ${ }^{34,35}$ and the Average Nucleotide Identity based on BLAST + (ANIb), Average Nucleotide Identity based on Mummer (ANIm), and Tetra Correlation Search (TETRA) values were calculated using JSpeciesWS ${ }^{36}$ between S. albidoflavus ANT_B131 genome and its phylogenetically closest species S. albidoflavus J1074 (accession number PRJNA180996) and S. albidoflavus SM254 (accession number PRJNA295319).

\section{Genome Mining.}

The genetic potential of Streptomyces albidoflavus ANT_B131 to produce secondary metabolites was analyzed using antiSMASH bacterial version $5^{37}$ (default parameters including Cluster Blast and Cluster Pfam analysis), and the manual curation was performed using BLAST (Basic Local Alignment Search Tool - NCBI/NIH). The genomes of S. albidoflavus J1074 and S. albidoflavus SM254 were also evaluated by antiSMASH, following the same conditions, and the BGCs were compared between the three strains.

\section{Cultivation of Streptomyces albidoflavus ANT_B131 in different culture media.}

The Streptomyces albidoflavus ANT_B131 was cultivated in three types of culture media with the aim to support the expression of BGCs related to secondary metabolites. The media selected were Nutrient Broth $\left(\mathrm{NB}\right.$, Oxoid $\left.\mathrm{T}^{\mathrm{w}}\right)$, ISP2 broth (yeast extract $4 \mathrm{g. \textrm {I } ^ { - 1 }}$, malt extract $10 \mathrm{g.l}^{-1}$, dextrose $4 \mathrm{~g} . \mathrm{I}^{-1}, \mathrm{pH} 7,2$ ) and GYE broth (glucose $15 \mathrm{~g} . \mathrm{I}^{-1}$, yeast extract $5 \mathrm{~g} . \mathrm{I}^{-1}, \mathrm{CaCl}_{2} \cdot 2 \mathrm{H}_{2} \mathrm{O} 0.2 \mathrm{~g} . \mathrm{I}^{-1}, \mathrm{pH} 7,0$ ), prepared with ASW. Starter cultures $(15 \mathrm{~mL})$ were used to scale toward larger volume cultures $(100 \mathrm{~mL})$ and incubated at $28^{\circ} \mathrm{C}$ for 
seven days under stationary conditions. The cultivation was performed in triplicate. Negative controls were conducted with the culture media without the bacterium growth.

\section{Extraction of metabolites from different culture media.}

Extracts were obtained by three different types of organic extractions. For each cultivation, we performed two aliquots of bacterial growth. In the first growth, we applied the liquid-liquid separation with ethyl acetate, as described above. In the second growth, we separated the cells, and extracted the intracellular metabolites with methanol. For this, the bacterial growth was centrifuged for 10 minutes $(5,000 \mathrm{rpm})$ and the cells were separated from the culture media. $80 \mathrm{~mL}$ of methanol was added to the cells, carried to ultrasonic bath for 40 minutes, and the organic phase was collected. To the culture media were added XAD-2 adsorbent (Sigma-Aldrich), kept under shaking (150 rpm) for 3 hours, and methanol was used to recover the metabolites adsorbed in XAD-2. The crude extracts were dried in a Rotary evaporator (Buchi® $\mathrm{R}$-215) under vacuum at $40^{\circ} \mathrm{C}$ and $80 \mathrm{rpm}$. The crude extracts were stored at $-20^{\circ} \mathrm{C}$ until the use in the assays. The experiment was performed for all the culture media evaluated in triplicate. Negative controls were conducted with the culture media without the bacterium growth.

\section{Mass Spectrometry analysis.}

Crude extracts were diluted in methanol and analyzed by HPLC-ESI-MS/MS in Agilent 6550 series Q-TOF (G6550A) Dual AJS ESI. Parameters were set on positive mode, capillary voltage $3.5 \mathrm{kV}$, inlet capillary temperature of $290^{\circ} \mathrm{C}$. Method TIC (Total lon Chromatogram) was selected for a general scan in 100$1700 \mathrm{~m} / z$ mass range. The injection volume of the samples was $2 \mu \mathrm{L}$. Stationary phase: Agilent 1260 Infinity C18 (2.1 mm x $100 \mathrm{~mm}$ ) column. Mobile phase: $0.1 \%$ formic acid (A) and acetonitrile (B). Eluent profile (A: B) 0-11 min, gradient from 2:98 up to 95:5; held for $5 \mathrm{~min}$. Flow rate: $0.3 \mathrm{~mL} \mathrm{~min}^{-1}$. MS/MS was performed by collision induced dissociation (CID with $\mathrm{m} / \mathrm{z}$ range of $100-1500$ and the collision energy of 30 V. Data was processed with MassHunter Qualitative Analysis B.07.00 software.

\section{Molecular Networking Analysis.}

ESI-MS/MS acquired data were subjected to msConvert ${ }^{38}$ to convert the files to format. $\mathrm{mzXML}$ and were analyzed by molecular networking in Global Natural Products Social Molecular Networking (GNPS) server $^{39}$. A molecular network for Streptomyces albidoflavus ANT_B131 extracts was created using the online workflow (https://ccms-ucsd.github.io/GNPSDocumentation/) on the GNPS website (http://gnps.ucsd.edu). MS/MS spectra were window filtered by choosing only the top 6 fragment ions in the +/- $50 \mathrm{Da}$ window throughout the spectrum. The precursor ion mass tolerance was set to $0.02 \mathrm{Da}$ and a MS/MS fragment ion tolerance of $0.02 \mathrm{Da}$. A network was then created where edges were filtered to have a cosine score above 0.5 and more than 5 matched peaks. Further, edges between two nodes were kept in the network if and only if each of the nodes appeared in each other's respective top 10 most 
similar nodes. Finally, the maximum size of a molecular family was set to 100 , and the lowest scoring edges were removed from molecular families until the molecular family size was below this threshold. The spectra in the network were then searched against GNPS' spectral libraries. The library spectra were filtered in the same manner as the input data. All matches kept between network spectra and library spectra were required to have a score above 0.5 and at least 5 matched peaks ${ }^{39}$. The resulting molecular networking is available at https://gnps.ucsd.edu/ProteoSAFe/status.jsp?

task=bf96ebe6282048678b8da1b1affdf138. The spectral networks were imported and visualized using Cytoscape 3.8.0 software (https://cytoscape.org/).

\section{Results And Discussion}

\section{The phylogenetic analysis and the in silico DNA-DNA hybridization correlated the ANT_B131 to Streptomyces albidoflavus.}

The Streptomyces albidoflavus ANT_B131 was isolated from Salp sp. collected in King George Island, Antarctica, during the summer of 2010. The phylogenetic identification using the sequencing of the $16 \mathrm{~S}$ RNAr gene indicated that ANT_B131 belongs to the Streptomyces genera (See Supplementary Fig. 1), and was closest related to a clade with Streptomyces albidoflavus DSM 40455, Streptomyces hydrogenans NBRC 13475, Streptomyces daghestanicus NRRL B-5418, and Streptomyces violascens ISP 5183. According to the List of Prokaryotic names with Standing in Nomenclature (LPSN) ${ }^{40}$ there are 660 species of Streptomyces with a validly published name. The 16S rRNA gene sequencing has an important role in the taxonomy of Streptomyces, however, it does not always have the power to delimit species ${ }^{41}$. To improve the taxonomic analysis, we choose to perform the Multilocus Sequence Analysis (MLSA) of house-keeping genes and the in silico DNA-DNA hybridization (isDDH). MLSA provide the improvement of taxonomic resolution among species within the family Streptomycetaceae $e^{42}$ and DDH is the gold standard for species delineation ${ }^{34}$.

The studied Streptomyces strain had its whole genome sequenced (accession number JADILI000000000) and, based on the genome annotation, five house-keeping genes were selected (see Supplementary Table 1) to the MLSA. The whole genome sequencing enables the comparation of the total genome of Streptomyces ANT_B131 with correlated strains, performing the isDDH. The DDH is a laborious technique, with which $\mathrm{G}+\mathrm{C}$ content and melting profiles have been estimated, and could be done by HPLC and realtime PCR. After the advantage of genome sequence techniques, the $\mathrm{G}+\mathrm{C}$ content analysis and the DDH between two bacterial genomes could be done in silico ${ }^{34}$.

The whole genome was sequenced with Illumina and assembled with SeqMan NGen version 14.0 software, resulting in a total genome length of 6,968,465 bp in 49 contigs, with an $N_{50}$ of 236,213 bp and a GC content of $73.2 \%$. The genome was annotated using Prokka that identified 6,110 coding sequences (CDSs), PGAP identified 6,055 protein-coding genes, Patric identified 6,459 CDS and RAST identified 
6,550 CDSs and 413 subsystems (Table 1). We provide a high-quality draft genome with $97.2 \%$ completeness, $0.6 \%$ duplicated and $0.3 \%$ fragmented.

Table 1

Genome annotation features of Streptomyces albidoflavus ANT_B131

\begin{tabular}{|lllll|}
\hline Feature & Prokka & PGAP & Patric & RAST \\
\hline CDS & 6,110 & 6,055 & 6,459 & 6,550 \\
\hline rRNA & 7 & 16 & 65 & 16 \\
\hline tRNA & 75 & 66 & 11 & 65 \\
\hline tmRNA & 1 & - & - & - \\
\hline misc RNA & 50 & - & - & - \\
\hline Subsystems & - & - & - & 413 \\
\hline
\end{tabular}

The MLSA included closest strains related to ANT_B131 and indicated that the Antarctic strain was closest related to Streptomyces albidoflavus NRRL B-1271 (Fig. 1). The average nucleotide identity based on BLAST + (ANIb) and in silico DNA-DNA hybridization (isDDH) values were calculated between ANT_B131 and its phylogenetically closest species S. albidoflavus J1074 (ANIb 97.02\%; isDDH 79.60\%; Difference in \% G + C: 0.15) and S. albidoflavus SM254 (ANIb 97.41; isDDH 79.50\%; Difference in \% G + C: 0.17 ) (see Supplementary Table 2). The ANI and isDDH were above the cutoff of $>95 \%$ and $>=70 \%$, respectively, and the difference in $\% \mathrm{G}+\mathrm{C}$ was $<1.0$, these results indicates that ANT_B131 belongs to the same species of the tested strains ${ }^{34,36}$. The DDH values (\%) are currently used as the gold standard for species delineation in bacteriology. The evaluation of the dDDH (digital DNA-DNA hybridization) enabled the delineation of the novel species Micromonospora zhangzhouensis, the productor of a diterpenoid with cytotoxic activity ${ }^{43}$. In this study, attending to taxonomic criteria applied to the genome sequence, it was possible to correlate the bacterium ANT_B131 to the species Streptomyces albidoflavus.

In general, the genomic results are in agreement with the characteristics of Streptomyces albidoflavus genomes previously reported on NCBI. There are 46 genomes related to Streptomyces albidoflavus deposited in GenBank (https://www.ncbi.nlm.nih.gov/genome/genomes/32384). The GC content ranging from 72.30 to $73.60 \%$ and the genome size ranging from $6.52 \mathrm{Mb}$ to $7.45 \mathrm{Mb}$. The median total length of the genomes is $7,053,130 \mathrm{bp}$, the median protein count is 5,964 and the median GC\% is 73.4 .

\section{Streptomyces albidoflavus ANT_B131 produces potential antimicrobials and antiproliferative.}

Organic crude extracts obtained by ethyl acetate solvent extraction showed antimicrobial and antiproliferative activities. The antimicrobial activity was observed against Gram-positive and Gramnegative pathogenic bacteria, and against the fungus Candida albicans (Table 2). The MIC ranged from 
0.25 to $2.0 \mathrm{mg} \cdot \mathrm{mL}^{-1}$. Antimicrobial activity related to crude extracts of Streptomyces isolated from Antarctica is documented against Gram-positive and Gram-negative bacteria, but little information is available about the antifungal activity of those crude extracts ${ }^{2,3}$.

The cytostatic antiproliferative activity of crude extracts were observed against cell lines: glioblastoma $\mathrm{U} 251\left(\mathrm{GI}_{50} 17.2 \mu \mathrm{L} . \mathrm{ml}^{-1}\right)$, human breast adenocarcinoma MCF-7 $\left(\mathrm{Gl}_{50} 195.3 \mu \mathrm{L} . \mathrm{ml}^{-1}\right)$, large cell carcinoma of lung NCl-H460 $\left(\mathrm{GI}_{50} 0.35 \mu \mathrm{L} . \mathrm{ml}^{-1}\right)$, adenocarcinoma of kidney $786-0\left(\mathrm{Gl}_{50} 27.7 \mu \mathrm{L} . \mathrm{ml}^{-1}\right)$, and prostate PC-3 $\left(\mathrm{Gl}_{50} 24.8 \mu \mathrm{L} . \mathrm{ml}^{-1}\right)$ (Fig. 2).

Table 2

Minimum inhibitory concentration (MIC) and Mininimum Bactericidal Concentration (MBC) of crude extracts of Streptomyces sp. ANTB_131.

Strain Origin $\quad \mathrm{MIC}(\mathrm{mg} / \mathrm{mL}) / \mathrm{MBC}(\mathrm{mg} / \mathrm{mL})$

\section{Gram-positive strains}

Bacillus subtilis ATCC 6051

DM/UNICAMP $\quad 0,5 / 1,5$

Micrococcus luteus ATCC 4698

DM/UNICAMP $\quad 0,25 /-$

Staphylococcus aureus ATCC 6538

DM/UNICAMP 2,0/-

\section{Gram-negative strains}

Neisseria meningitidis Y USA (Clinical isolation) INCQS/FIOCRUZ 2,0 / -

Neisseria meningitidis C 2135

INCQS/FIOCRUZ 2,0/-

Neisseria meningitidis B4 (Clinical isolation)

Neisseria meningitidis W135 ATCC35559

INCQS/FIOCRUZ 2,0/-

INCQS/FIOCRUZ 2,0/-

Fungi strain

Candida albicans ATCC10231

DM/UNICAMP $\quad 1,5 / 1,5$

INCQS/FIOCRUZ: Special Laboratory of Bacteriology and Molecular Epidemiology, Department of Clinical, Toxicological and Bromatological Analysis, São Paulo State University (USP), Ribeirao Preto, SP, Brazil. DM/UNICAMP: Division of Microbiology, University of Campinas (UNICAMP), Paulínia, SP, Brazil. LABIOTEC: Biotechnology Laboratory, Faculty of Pharmaceutical Sciences, Campinas State University (UNICAMP), Campinas, SP, Brazil. ATCC: American Type Culture Collection.

\section{Genome mining uncovers the genomic potential for Streptomyces albidoflavus ANT_B131 to produce natural products.}

The genome mining study was performed using antiSMASH database and the manual curation revealed 24 putative Biosynthetic Gene Clusters (BGCs). The BGC encoding polyketides type I (5 of 24) and type III 
(1 of 24), non-ribosomal peptides (NRPS, 8 of 24), bacteriocins (2 of 24), terpenes (4 of 24), siderophores (2 of 24), hybrid compounds (4 of 24), ectoine, thiopeptide, lanthipeptide, and lassopeptide (Fig. 3 , Table 3).

Despite the antiSMASH analysis, the manual curation validated the identification of three fragments of genes clusters related to surugamide A/D (cluster 13) and three related to candicidin (cluster 19). The surugamide A/D BGC had 82,441 bp and encodes a non-ribosomal peptide described as a antibacterial and antifungal compound ${ }^{44}$. The candicidin BGC had 138,203 bp and the correspondent metabolite showed antimicrobial activity against Candida albicans ${ }^{45}$.

The bioinformatic analysis by antiSMASH predicted terpenes with high BGC similarity: hopene (cluster 4, $100 \%$ of similarity), the volatile compound geosmin (cluster $8,100 \%$ of similarity), the sesquiterpene antibiotic albaflavenone (cluster $9,100 \%$ of similarity), the carotenoid Isorenieratene (cluster $17,75 \%$ of similarity), naringenin (cluster $18,100 \%$ of similarity). Albaflavenone and geosmin are responsible for the strong odor in streptomycete and are related to antimicrobial activity ${ }^{46}$. Interestingly, antiSMASH identified the gene cluster of SGR PTMs (cluster $3,100 \%$ of similarity) related to a polycyclic tetramate macrolactams first identified in Streptomyces griseus. The Desferrioxamine B/E (cluster 15) and Ectoine (cluster 16) BGCs showed $100 \%$ of gene similarity. The Desferrioxamine B is a $\mathrm{Fe}$ (III) chelator, and is associated to iron deliver to microbes ${ }^{47}$. Ectoine provides protection against osmotic stress ${ }^{48}$. The antimycin BGC (cluster $23,80 \%$ of similarity) is a secondary metabolite of Streptomyces sp. with cytotoxic, antifungal, antibiotic, anticancer activities ${ }^{49}$. The BGCs relate to kanamycin (cluster 8), thiopeptides fluostatins M-Q (cluster 10) and type I PKS Pacificanone A (cluster 20) showed less than $20 \%$ of similarity. 
Table 3

Biosynthetic gene clusters identified in the genome of Streptomyces albidoflavus ANT_B131.

\begin{tabular}{|c|c|c|c|c|}
\hline Number & Cluster location & $\begin{array}{l}\text { Cluster size } \\
\text { (kb) }\end{array}$ & Type & Predicted product \\
\hline 1 & $\begin{array}{l}\text { Contig } 79 \text { (164714 to } \\
210406)\end{array}$ & 45693 & NRPS & Diisonitrile antibiotic SF2768 \\
\hline 2 & $\begin{array}{l}\text { Contig } 79 \text { (229633 to } \\
304621)\end{array}$ & 74989 & $\begin{array}{l}\text { NRPS / } \\
\text { Terpene }\end{array}$ & Orphan \\
\hline 3 & $\begin{array}{l}\text { Contig } 79 \text { (423354 to } \\
472764)\end{array}$ & 49411 & $\begin{array}{l}\text { NRPS / } \\
\text { T1PKS }\end{array}$ & SGR PTMs \\
\hline 4 & $\begin{array}{l}\text { Contig } 79 \text { (503123 to } \\
529681)\end{array}$ & 26559 & Terpene & Hopene \\
\hline 5 & $\begin{array}{l}\text { Contig } 79 \text { (608808 to } \\
619023)\end{array}$ & 10216 & Bacteriocin & Orphan \\
\hline 6 & $\begin{array}{l}\text { Contig } 42 \text { (6276 to } \\
\text { 17604) }\end{array}$ & 11329 & Bacteriocin & Orphan \\
\hline 7 & $\begin{array}{l}\text { Contig } 66 \text { (20876 to } \\
35889)\end{array}$ & 15013 & Siderophore & Orphan \\
\hline 8 & $\begin{array}{l}\text { Contig } 104 \text { (6303 to } \\
28603)\end{array}$ & 22301 & $\begin{array}{l}\text { Terpene / } \\
\text { Other }\end{array}$ & Geosmin/Kanamycin \\
\hline 9 & $\begin{array}{l}\text { Contig } 52 \text { (386568 to } \\
407620)\end{array}$ & 21053 & Terpene & Albaflavenone \\
\hline 10 & $\begin{array}{l}\text { Contig } 2 \text { (123277 to } \\
\text { 155794) }\end{array}$ & 32473 & Thiopeptide & Fluostatins $\mathrm{M}-\mathrm{Q}$ \\
\hline 11 & $\begin{array}{l}\text { Contig } 10 \text { (163019 to } \\
224651 \text { ) }\end{array}$ & 48914 & NRPS & Orphan \\
\hline 12 & $\begin{array}{l}\text { Contig } 10 \text { (263300 to } \\
313589)\end{array}$ & 62236 & NRPS & Orphan \\
\hline \multirow[t]{3}{*}{13} & Contig 80 (1 to 29890 ) & 29890 & NRPS & $\begin{array}{l}\text { Surugamide A / Surugamide } \\
\text { D }\end{array}$ \\
\hline & Contig 33 (1 to 41377 ) & 41377 & NRPS & $\begin{array}{l}\text { Surugamide A / Surugamide } \\
\text { D }\end{array}$ \\
\hline & $\begin{array}{l}\text { Contig } 102 \text { (46186 to } \\
77679)\end{array}$ & 30893 & NRPS & $\begin{array}{l}\text { Surugamide A / Surugamide } \\
\text { D }\end{array}$ \\
\hline 14 & $\begin{array}{l}\text { Contig } 71 \text { (189212 to } \\
233561)\end{array}$ & 44395 & NRPS & Orphan \\
\hline 15 & $\begin{array}{l}\text { Contig } 83 \text { (59655 to } \\
71475 \text { ) }\end{array}$ & 11820 & Siderophore & $\begin{array}{l}\text { Desferrioxamine B / } \\
\text { Desferrioxamine E }\end{array}$ \\
\hline
\end{tabular}




\begin{tabular}{|c|c|c|c|c|}
\hline Number & Cluster location & $\begin{array}{l}\text { Cluster size } \\
(\mathrm{kb})\end{array}$ & Type & Predicted product \\
\hline 16 & $\begin{array}{l}\text { Contig } 81 \text { (106501 to } \\
116899 \text { ) }\end{array}$ & 10399 & Ectoine & Ectoine \\
\hline 17 & $\begin{array}{l}\text { Contig } 55 \text { (39767 to } \\
65616)\end{array}$ & 25849 & Terpene & Isorenieratene \\
\hline 18 & $\begin{array}{l}\text { Contig } 85 \text { (1860 to } \\
\text { 42957) }\end{array}$ & 41097 & T3PKS & Naringenin \\
\hline \multirow[t]{3}{*}{19} & $\begin{array}{l}\text { Contig } 85 \text { (47893 to } \\
101940 \text { ) }\end{array}$ & 54047 & T1PKS & Candicidin \\
\hline & Contig 3 ( 1 to 22674 ) & 22674 & T1PKS & Candicidin \\
\hline & $\begin{array}{l}\text { Contig } 25 \text { (11507 to } \\
\text { 70522) }\end{array}$ & 59015 & T1PKS & Candicidin \\
\hline 20 & Contig 21 (1 to 31408 ) & 31408 & T1PKS & Pacificanone A \\
\hline 21 & Contig 27 ( 1 to 5181 ) & 5181 & T1PKS & Orphan \\
\hline 22 & Contig 40 (1 to 4749 ) & 4749 & T1PKS & Orphan \\
\hline 23 & Contig 47 (1 to 74671 ) & 74671 & NRPS-T1PKS & Antimycin \\
\hline 24 & $\begin{array}{l}\text { Contig } 22 \text { (74379 to } \\
96762 \text { ) }\end{array}$ & 22384 & Lassopeptide & Orphan \\
\hline
\end{tabular}

In the antiSMASH analysis of the genomes of the two strains closest related to the Streptomyces albidoflavus ANT_B131, we found similarities in the BGCs number and type. The BGCs identification (Fig. 4) indicated that are common types of core biosynthetic genes for secondary metabolites production between the three strains, such as, the NRPS, PKS, Hybrid PKS-NRPS, Terpene and Siderophore. The metabolites hopene, geosmin, surugamide, desferrioxamine B, candicidin, ectoine, isorenieratene and SGR-PTM were identified in all the genomes with similarity above $75 \%$. Biosynthetic clusters related to RiPPs, such as lanthipeptides, thiopeptides and bacteriocins were also found. However, a blast analysis did not show similarity between the RiPPs BGCs of Streptomyces albidoflavus or even other bacteria. This result indicated that these orphan clusters (clusters $6,10,28$, and 30 ) have a potential to be new molecules with unknow biological activities.

The three strains showed closest percentage of the genome attributed to biosynthetic genes involved in secondary metabolite production. Streptomyces albidoflavus ANT_B131 had 13.3\% (925,376 bp) of the genome related to the secondary metabolism, S. albidoflavus SM254, genome size 7,170,505 bp, attributed $13.58 \%$ and S. albidoflavus J1074, genome size 6,841,649 bp, attributed $13.0 \%$ of the genome.

\section{Five BGCs were expressed}


After the genome sequencing and the BGC identification by antiSMASH, we performed an experiment to improve the expression of the biosynthetic gene clusters related to the secondary metabolites production. The Classical Molecular Networking analysis by GNPS enables the identification of compounds related to BGCs. GNPS provides the processes, analysis or identification of tandem mass (MS/MS) spectrometry data of a data set and compare the data to all publicly available data ${ }^{39}$. To generate networks, Molecular Networking utilizes the MS/MS data. The nodes, in the network, represent molecules and edges represent spectral similarity between pairs of molecules ${ }^{12}$.

MS/MS spectra of S. albidoflavus ANT_B131 extracts were identified as a hit in GNPS database (see Supplementary Fig. 2-5) and four metabolites were putatively identified: surugamide A (1), surugamide D (2), desferrioxamine B $+\mathrm{Al}(3)$ and desferrioxamine $\mathrm{E}$ (4). Also, based on the MS/MS spectra and comparison with other databases (METLIN and MassBank of North America), the metabolite ectoine (5) was manually identified in S. albidoflavus extracts (see Supplementary Fig. 6). The identified compounds were detected only in the bacterial extracts and absent in the controls (culture media extracts) (see Supplementary Fig. 6-10), and all their structures are represented in Fig. 5. The MS data of the detected metabolites have mass errors below 5 ppm and are shown in Table 4.

Table 4

Genome annotation features of Streptomyces albidoflavus ANT_B131

\begin{tabular}{|c|c|c|c|c|c|}
\hline Compound & Ion & Ion Formula & $\begin{array}{l}\text { Calculated } \\
\mathrm{m} / \mathbf{z}\end{array}$ & $\begin{array}{l}\text { Experimental } \\
\mathrm{m} / \mathrm{z}\end{array}$ & $\begin{array}{l}\text { Error } \\
\text { (ppm) }\end{array}$ \\
\hline Surugamide A & {$[\mathrm{M}+\mathrm{H}]^{+}$} & $\mathrm{C}_{48} \mathrm{H}_{82} \mathrm{~N}_{9} \mathrm{O}_{8}$ & 912.6286 & 912.6294 & 0.9 \\
\hline Surugamide D & {$[\mathrm{M}+\mathrm{H}]^{+}$} & $\mathrm{C}_{47} \mathrm{H}_{80} \mathrm{~N}_{9} \mathrm{O}_{8}$ & 898.6129 & 898.6116 & -1.4 \\
\hline $\begin{array}{l}\text { Desferrioxamine B } \\
+\mathrm{Al}\end{array}$ & $\begin{array}{l}{[\mathrm{M}-2 \mathrm{H}+} \\
\mathrm{All}]^{+}\end{array}$ & $\mathrm{C}_{25} \mathrm{H}_{46} \mathrm{~N}_{6} \mathrm{O}_{8} \mathrm{Al}$ & 585.3192 & 585.3202 & 1.7 \\
\hline Desferrioxamine E & {$[\mathrm{M}+\mathrm{Na}]^{+}$} & $\mathrm{C}_{27} \mathrm{H}_{48} \mathrm{~N}_{6} \mathrm{O}_{9} \mathrm{Na}$ & 623.3380 & 623.3404 & 3.8 \\
\hline Ectoine & {$[\mathrm{M}+\mathrm{H}]^{+}$} & $\mathrm{C}_{6} \mathrm{H}_{11} \mathrm{~N}_{2} \mathrm{O}_{2}$ & 143.0820 & 143.0818 & -1.4 \\
\hline
\end{tabular}

Ion $[\mathrm{M}+\mathrm{H}]^{+}$at $m / z 912.6294$ was identified as compound 1. MS/MS spectrum of this ion yielded to fragments at $m / z 261.1602,298.2084,374.2498,539.3926,652.4693$ and 884.6316 , typical fragments for the structure of 1 (see Supplementary Fig. 7E) and already reported in the literature ${ }^{50}$. Also, surugamide 2 was identified as ion $[\mathrm{M}+\mathrm{H}]^{+}$at $m / z$ 898.6116. Fragmentation of 2 was close to fragmentation of 1 due structure similarity (see Supplementary Fig. $8 \mathrm{E}$ ) and yielded to fragments $261.1600,374.2493,638.4719$ and 785.5196. Surugamide 1 was identified as intracellular and extracellular metabolite. Compound 1 was found in the mycelium and the media of two media, NB-ASW and GYE-ASW, when applied methanol as extract solvent (Fig. 6). However, compound 2 was identified only as intracellular metabolite of all culture media evaluated, also recovered by methanol extraction. 
Surugamide 1 was reported with antifungal activity against Saccharomyces cerevisae and was expressed in Streptomyces albidoflavus $\mathrm{J} 1074^{44}$, antimicrobial activity against Staphylococcus aureus (MIC of $10 \mu \mathrm{M})^{51}$, and inhibit bovine cathepsin $\mathrm{B}\left(\mathrm{IC}_{50} \text { of } 21 \mu \mathrm{M}\right)^{52}$, a cysteine protease that implicated in invasion of metastatic tumor cells. Surugamide 2 showed the inhibitory activity against bovine cathepsin $B\left(\mathrm{IC}_{50} \text { of } 18 \mu \mathrm{M}\right)^{52}$.

GNPS database identified ions $[\mathrm{M}-2 \mathrm{H}+\mathrm{Al}]^{+}$at $m / z 585.3202$ and $[\mathrm{M}+\mathrm{Na}]^{+}$at $m / z 623.3404$ as desferrioxamines $B$ and $E$, respectively. MS/MS spectrum of $\mathbf{3}$ yielded to fragments at $m / z 385.2015$, $425.1973,467.2067$ and 568.2982, typical fragmentation pattern for the structure of desferrioxamine B complexed with $\mathrm{Al}(\mathrm{III})$ (see Supplementary Fig. 9E). Close fragmentation pattern was reported for desferrioxamine B complexed with Fe(III) (difference of $29 \mathrm{Da}$ in the mass fragments due the difference of mass between $\mathrm{Al}$ and $\mathrm{Fe})^{53}$. For compound $\mathbf{4}$, mass fragmentation yielded to fragments at $\mathrm{m} / \mathrm{z}$ 423.2225 and 223.1101, this fragmentation pattern corresponds to the typical neutral losses of molecules of succinylcadaverine $(200.1160 \mathrm{Da})^{54}$. Compounds $\mathbf{3}$ and $\mathbf{4}$ were recovery using all types of extraction methods when GYE-ASW medium was used to bacterial growth. The compounds were also identified as intra and extracellular metabolite of ISP2-ASW medium, recovered by methanol extraction. Compound $\mathbf{3}$ was identified as in NB-ASW medium using methanol as extraction solvent (see Supplementary Fig. 7). Desferrioxamine B is an iron-chelating agent used clinically to treat pathological iron deposition in human and iron poisoning, as $\mathrm{Al}(\mathrm{III})^{55}$. The antimicrobial activity of desferrioxamine $\mathrm{B}$ against $E$. coli is related to inhibition of bacterial motility ${ }^{56}$. Desferrioxamine $E$ or nocardamine belongs to a group of microbial siderophores and has weak antimicrobial activity against $E$. faecium and $B$. subtilis and showed inhibition of colony formation of melanoma cancer cells $\left(\mathrm{IC}_{50} \text { from } 12 \text { to } 18 \mu \mathrm{M}\right)^{57}$.

Ion $[\mathrm{M}+\mathrm{H}]^{+}$at $m / z 143.0818$ were identified as compound $\mathbf{5}$, and yielded to fragments at $\mathrm{m} / \mathrm{z} 101.0706$ and 113.5968. MS/MS spectra of ectoine at METLIN and MassBank of North America databases showed close fragmentation pattern, with fragment at $\mathrm{m} / \mathrm{z} 101.0709$ as one of the main fragments for compound 5 (see Supplementary Fig. 6E). Compound $\mathbf{5}$ was identified as intracellular metabolite in methanolic extract of all culture media. Also, the compound could be identified in the NB-ASW culture medium as an extracellular metabolite recovered by methanol extraction (Fig. 6). Ectoine has an important role as osmoprotectant, helps to prevent whole cell damage and loss of viability ${ }^{58}$. The crude extract of NB-ASW medium extracted using ethyl acetate was the extract used for the biological assays, antiproliferative and antimicrobial. However, the GNPS database did not correlate any secondary metabolite to this crude extract.

These results revealed that the use of different culture media enabled the condition to Streptomyces albidoflavus ANT_B131 express the BGCs related to the secondary metabolites. Also, the different extraction methods and solvents enable the recovery of these compounds. In this study, we could express $20 \%$ of the BGCs identified by antiSMASH (5 of 25). Studies conducted on Streptomyces fildesensis S013.3 and Pseudoalteromonas luteoviolacea showed the expression of zero and 10\% of the BGCs identified, respectively ${ }^{2,59}$. We showed that the diversity of culture media and extraction methods could 
enhance the BGCs expression and recovery of natural products. This approach could be a new strategy to intensify the BGC expression of natural products.

Genome mining made possible the identification of BGCs related to RiPPs, such as bacteriocins, thiopeptide and lassopeptide. These clusters did not presented similarity with none BGC described in literature and Molecular Networking analysis did not show results for any class of RiPPs, but further work is required to detect their production in these organisms. The heterologous expression is a potential tool to discover these natural products.

Besides the efforts to get the compounds that showed similarities with biosynthetic gene clusters, we could not correlate any of the compounds identified in this study to the crude extract that showed antimicrobial and antiproliferative activity, the growth in NB-ASW media and extracted by ethyl acetate. Additional genome and biological assays should be done to confirm the presence and novelty of secondary metabolites for this condition and activity. Also, heterologous expression will be applicable, in future study, to get the orphan BGCs undefined associated to S. albidoflavus ANT_B131 genome.

\section{Declarations}

\section{Competing Interest: No}

\section{References}

1. Harvey, A. L., Edrada-Ebel, R. \& Quinn, R. J. The re-emergence of natural products for drug discovery in the genomics era. Nat. Rev. Drug Discov. 14, 111-129 (2015).

2. Núñez-Montero, K. et al. Antarctic Streptomyces fildesensis So13.3 strain as a promising source for antimicrobials discovery. Sci. Rep. 9, 1-13 (2019).

3. Danilovich, M. E., Sánchez, L. A., Acosta, F. \& Delgado, O. D. Antarctic bioprospecting: in pursuit of microorganisms producing new antimicrobials and enzymes. Polar Biol. 41, 1417-1433 (2018).

4. Lamilla, C. et al. Bioprospecting for extracellular enzymes from culturable Actinobacteria from the South Shetland Islands, Antarctica. Polar Biol. 40, 719-726 (2017).

5. Lavin, P. L., Yong, S. T., Wong, C. M. V. L. \& De Stefano, M. Isolation and characterization of Antarctic psychrotroph Streptomyces sp. strain INACH3013. Antarct. Sci. 28, 433-442 (2016).

6. Jeon, Y. J., Kim, S., Kim, J. H., Youn, U. J. \& Suh, S. S. The comprehensive roles of ATRANORIN, a secondary metabolite from the antarctic lichen stereocaulon caespitosum, in HCC tumorigenesis. Molecules 24, (2019).

7. Parrilli, E. et al. The art of adapting to extreme environments: The model system Pseudoalteromonas. Phys. Life Rev. (2019) doi:10.1016/j.plrev.2019.04.003.

8. Tracanna, V., de Jong, A., Medema, M. H. \& Kuipers, O. P. Mining prokaryotes for antimicrobial compounds: From diversity to function. FEMS Microbiol. Rev. 41, 417-429 (2017). 
9. Khalifa, S. A. M. et al. Marine natural products: A source of novel anticancer drugs. Mar. Drugs 17, (2019).

10. Berdi, J. J. 58(1): 1-26, 2005. J. Antibiot. Antibiot. 58, 1-26 (2005).

11. Soldatou, S., Eldjarn, G. H., Huerta-Uribe, A., Rogers, S. \& Duncan, K. R. Linking biosynthetic and chemical space to accelerate microbial secondary metabolite discovery. FEMS Microbiol. Lett. 366, 1-8 (2019).

12. Ziemert, N., Weber, T. \& Medema, M. H. Genome Mining Approaches to Bacterial Natural Product Discovery. Comprehensive Natural Products III (Elsevier Inc., 2020). doi:10.1016/b978-0-12-4095472.14627-x.

13. Pospiech, A. \& Neumann, B. A versatile quick-prep of genomic DNA from Gram-positive bacteria. Trends Genet. 11, 217-218 (1995).

14. Ewing, B. \& Green, P. Base-calling of automated sequencer traces using phred. II. Error probabilities. Genome Res. 8, 186-194 (1998).

15. Gordon, D., Abajian, C. \& Green, P. Consed: A graphical tool for sequence finishing. Genome Res. 8 , 195-202 (1998).

16. Wang, Q., Garrity, G. M., Tiedje, J. M. \& Cole, J. R. Naïve Bayesian classifier for rapid assignment of rRNA sequences into the new bacterial taxonomy. Appl. Environ. Microbiol. 73, 5261-5267 (2007).

17. Yoon, S. H. et al. Introducing EzBioCloud: A taxonomically united database of $16 \mathrm{~S}$ rRNA gene sequences and whole-genome assemblies. Int. J. Syst. Evol. Microbiol. 67, 1613-1617 (2017).

18. Thompson, J. D., Higgins, D. G. \& Gibson, T. J. CLUSTAL W: Improving the sensitivity of progressive multiple sequence alignment through sequence weighting, position-specific gap penalties and weight matrix choice. Nucleic Acids Res. 22, 4673-4680 (1994).

19. Kumar, S., Stecher, G., Li, M., Knyaz, C. \& Tamura, K. MEGA X: Molecular evolutionary genetics analysis across computing platforms. Mol. Biol. Evol. 35, 1547-1549 (2018).

20. Kimura, M. A simple method for estimating evolutionary rates of base substitutions through comparative studies of nucleotide sequences. J. Mol. Evol. 16, 111-120 (1980).

21. Saitou, N. \& Nei, M. The neighbor-joining method: a new method for reconstructing phylogenetic trees. Mol. Biol. Evol. 4, 406-425 (1987).

22. Felsenstein, J. Confidence Limits on Phylogenies: an Approach Using the Bootstrap. Evolution (N. Y). 39, 783-791 (1985).

23. Rex, J. H. et al. Reference method for broth dilution antifungal susceptibility testing of yeasts. Clin. Lab. Stand. Inst. 28, 1-46 (2008).

24. Carpenter, D. E. et al. Methods for Antimicrobial Susceptibility Testing of Anaerobic Bacteria. Clin. Lab. Stand. Inst. 9, 1-64 (2018).

25. Weinstein, M. P. et al. Methods for Dilution Antimicrobial Susceptibility Tests for Bacteria That Grow Aerobically. Clin. Lab. Stand. Inst. 12, 1-112 (2018). 
26. Monks, A. et al. Feasibility of a high-flux anticancer drug screen using a diverse panel of cultured human tumor cell lines. J. Natl. Cancer Inst. 83, 757-766 (1991).

27. Bolger, A. M., Lohse, M. \& Usadel, B. Trimmomatic: A flexible trimmer for Illumina sequence data. Bioinformatics 30, 2114-2120 (2014).

28. Gurevich, A., Saveliev, V., Vyahhi, N. \& Tesler, G. QUAST: Quality assessment tool for genome assemblies. Bioinformatics 29, 1072-1075 (2013).

29. Darling, A. E., Mau, B. \& Perna, N. T. Progressivemauve: Multiple genome alignment with gene gain, loss and rearrangement. PLoS One 5, (2010).

30. Tatusova, T. et al. NCBI prokaryotic genome annotation pipeline. Nucleic Acids Res. 44, 6614-6624 (2016).

31. Brettin, T. et al. RASTtk: A modular and extensible implementation of the RAST algorithm for building custom annotation pipelines and annotating batches of genomes. Sci. Rep. 5, (2015).

32. Wattam, A. R. et al. Improvements to PATRIC, the all-bacterial bioinformatics database and analysis resource center. Nucleic Acids Res. 45, D535-D542 (2017).

33. Simão, F. A., Waterhouse, R. M., loannidis, P., Kriventseva, E. V. \& Zdobnov, E. M. BUSCO: Assessing genome assembly and annotation completeness with single-copy orthologs. Bioinformatics 31, 3210-3212 (2015).

34. Meier-kolthoff, J. P., Klenk, H. \& Go, M. Taxonomic use of DNA G + C content and DNA - DNA hybridization in the genomic age. 352-356 (2014) doi:10.1099/ijs.0.056994-0.

35. Meier-Kolthoff, J. P., Auch, A. F., Klenk, H. P. \& Göker, M. Genome sequence-based species delimitation with confidence intervals and improved distance functions. BMC Bioinformatics 14, (2013).

36. Richter, M., Rosselló-Móra, R., Oliver Glöckner, F. \& Peplies, J. JSpeciesWS: A web server for prokaryotic species circumscription based on pairwise genome comparison. Bioinformatics 32, 929931 (2016).

37. Blin, K. et al. AntiSMASH 5.0: Updates to the secondary metabolite genome mining pipeline. Nucleic Acids Res. 47, W81-W87 (2019).

38. Chambers, M. C. et al. A cross-platform toolkit for mass spectrometry and proteomics. Nat. Biotechnol. 30, 918-920 (2012).

39. Wang, M., Carver, J., Phelan, V. \& Al., E. Sharing and community curation of mass spectrometry data with Global Natural Products Social Molecular Networking. 34, 828-837 (2016).

40. Parte, A. C., Sardà Carbasse, J., Meier-Kolthoff, J. P., Reimer, L. C. \& Göker, M. List of Prokaryotic names with Standing in Nomenclature (LPSN) moves to the DSMZ. Int. J. Syst. Evol. Microbiol. 0-5 (2020) doi:10.1099/ijsem.0.004332.

41. Labeda, D. P. et al. Phylogenetic study of the species within the family Streptomycetaceae. Antonie van Leeuwenhoek, Int. J. Gen. Mol. Microbiol. 101, 73-104 (2012).

42. Labeda, D. P. et al. Phylogenetic relationships in the family Streptomycetaceae using multi-locus sequence analysis. Antonie van Leeuwenhoek, Int. J. Gen. Mol. Microbiol. 110, 563-583 (2017). 
43. Fu, G. et al. Micromonospora zhangzhouensis sp. nov., a Novel Actinobacterium Isolated from Mangrove Soil, Exerts a Cytotoxic Activity in vitro. Sci. Rep. 10, 1-12 (2020).

44. Xu, F., Nazari, B., Moon, K., Bushin, L. B. \& Mohammad, R. S. Discovery of a Cryptic Antifungal Compound from Streptomyces albus J1074 Using High-Throughput Elicitor Screens. J Am Chem Soc 139, 9203-9212 (2017).

45. Chen, S. et al. Organizational and Mutational Analysis of a Complete FR-008/Candicidin Gene Cluster Encoding a Structurally Related Polyene Complex. Chem. Biol. 10, 1065-1076 (2003).

46. Schöller, C. E. G., Gürtler, H., Pedersen, R., Molin, S. \& Wilkins, K. Volatile metabolites from actinomycetes. J. Agric. Food Chem. 50, 2615-2621 (2002).

47. Raines, D. J., Sanderson, T., Wilde, E. \& Duhme-Klair, A.-K. Siderophores. Reference Module in Chemistry, Molecular Sciences and Chemical Engineering (2015). doi:10.1016/B978-0-12-4095472.11040-6.

48. Prabhu, J., Schauwecker, F., Grammel, N., Keller, U. \& Bernhard, M. Functional expression of the ectoine hydroxylase gene (thpD) from Streptomyces chrysomallus in Halomonas elongata. Appl. Environ. Microbiol. 70, 3130-3132 (2004).

49. Liu, J., Zhu, X., Kim, S. J. \& Zhang, W. Antimycin-type depsipeptides: Discovery, biosynthesis, chemical synthesis, and bioactivities. Nat. Prod. Rep. 33, 1146-1165 (2016).

50. Thankachan, D. et al. A trans-Acting Cyclase Offloading Strategy for Nonribosomal Peptide Synthetases. ACS Chem. Biol. 14, 845-849 (2019).

51. Wang, X. et al. Mullinamides A and B, new cyclopeptides produced by the Ruth Mullins coal mine fire isolate Streptomyces sp. RM-27-46. J Antibiot. 67, 571-575 (2014).

52. Takada, K. et al. Surugamides A - E, Cyclic Octapeptides with Four D-Amino Acid Residues, from a Marine Streptomyces sp.: LC-MS-Aided Inspection of Partial Hydrolysates for the Distinction of Dand L-Amino Acid Residues in the Sequence. J. Org. Chem. 78, 6746-6750 (2013).

53. Pluhacek, T. et al. Characterization of microbial siderophores by mass spectrometry. Mass Spectrom. Rev. 35, 35-47 (2014).

54. Angolini, C. F. F. et al. Genome mining of endophytic streptomyces wadayamensis reveals high antibiotic production capability. J. Braz. Chem. Soc. 27, 1465-1475 (2016).

55. Kiss, T. \& Farkas, E. Metal-binding ability of Desferrioxamine B. J. Incl. Phenom. Mol. Recognit. Chem. 32, 385-403 (1998).

56. Maruyama, H. B., Azuma, H., Kotoh, Y. \& Suhara, Y. Desferrioxamine B, an inhibitor of Escherichia coli motility, reversing the stimulating effect of cyclic adenosine $3^{\prime}, 5^{\prime}$ monophosphate. Antimicrob.Agents Chemother. 7, 377-380 (1975).

57. Kalinovskaya, N. I., Romanenko, L. A., Irisawa, T., Ermakova, S. P. \& Kalinovsky, A. I. Marine isolate Citricoccus sp. KMM 3890 as a source of a cyclic siderophore nocardamine with antitumor activity. Microbiol. Res. 166, 654-661 (2011). 
58. Pastor, J. M. et al. Ectoines in cell stress protection: Uses and biotechnological production. Biotechnol. Adv. 28, 782-801 (2010).

59. Maansson, M. et al. An Integrated Metabolomic and Genomic Mining Workflow To Uncover the Biosynthetic Potential of Bacteria. mSystems 1, 1-14 (2016).

\section{Figures}

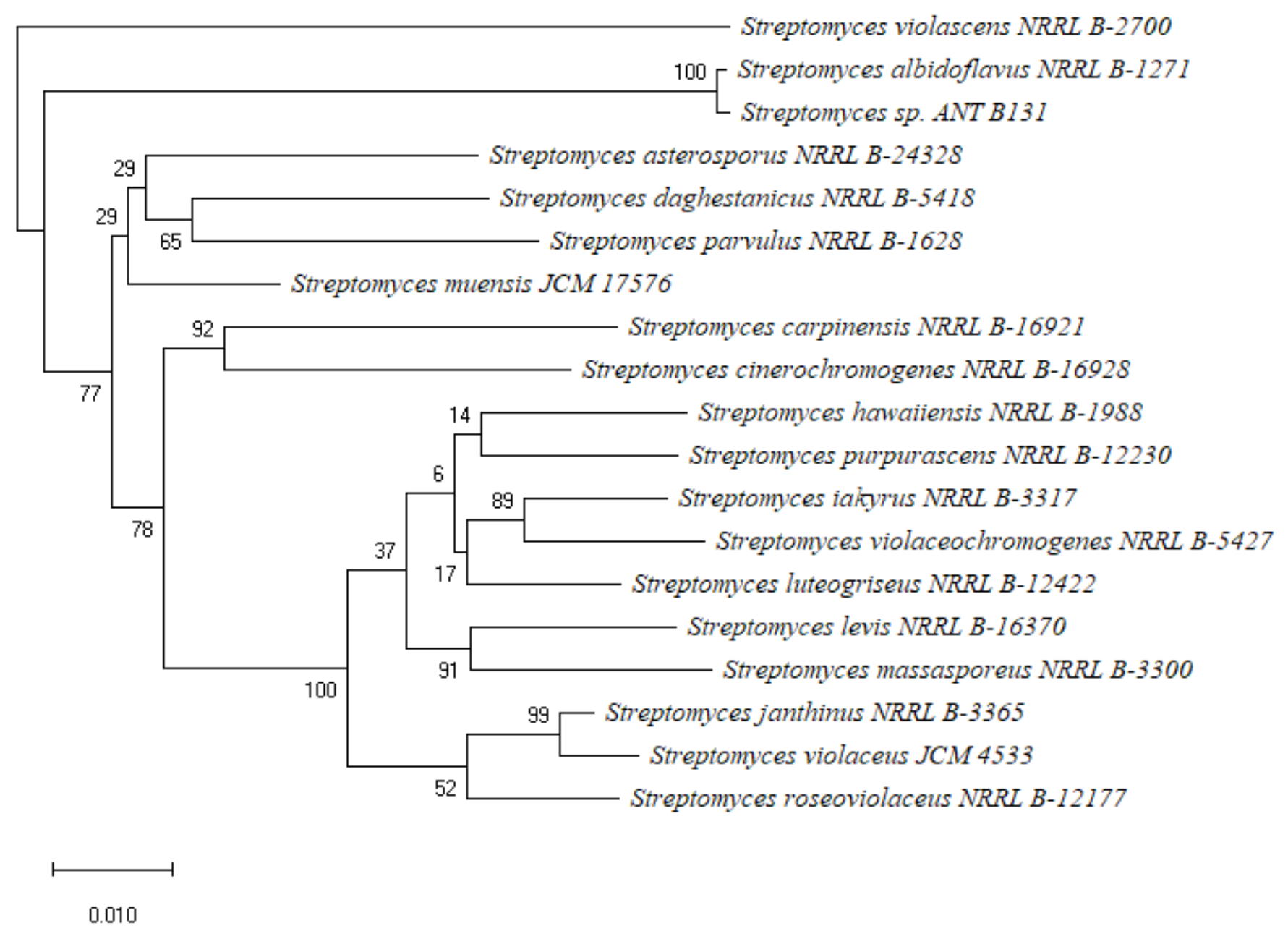

\section{Figure 1}

Multilocus Sequence Analysis (MLSA) of the genes sequence of atpD (ATP synthase F1, beta subunit), gyrB (DNA gyrase $B$ subunit), rpoB (RNA polymerase beta subunit), recA (recombinase $A$ ), and trpB (tryptophan synthetase, beta subunit A) of the ANTB_131 bacteria isolated from Antarctic and related microorganisms. Evolutionary distances were based on Kimura $2 p$ model and tree reconstruction on the neighbor-joining method. Bootstrap values (1000 repetitions, showed as \%) are listed. Scale bar represents 1 nucleotide substitution per 100 nucleotides position. 


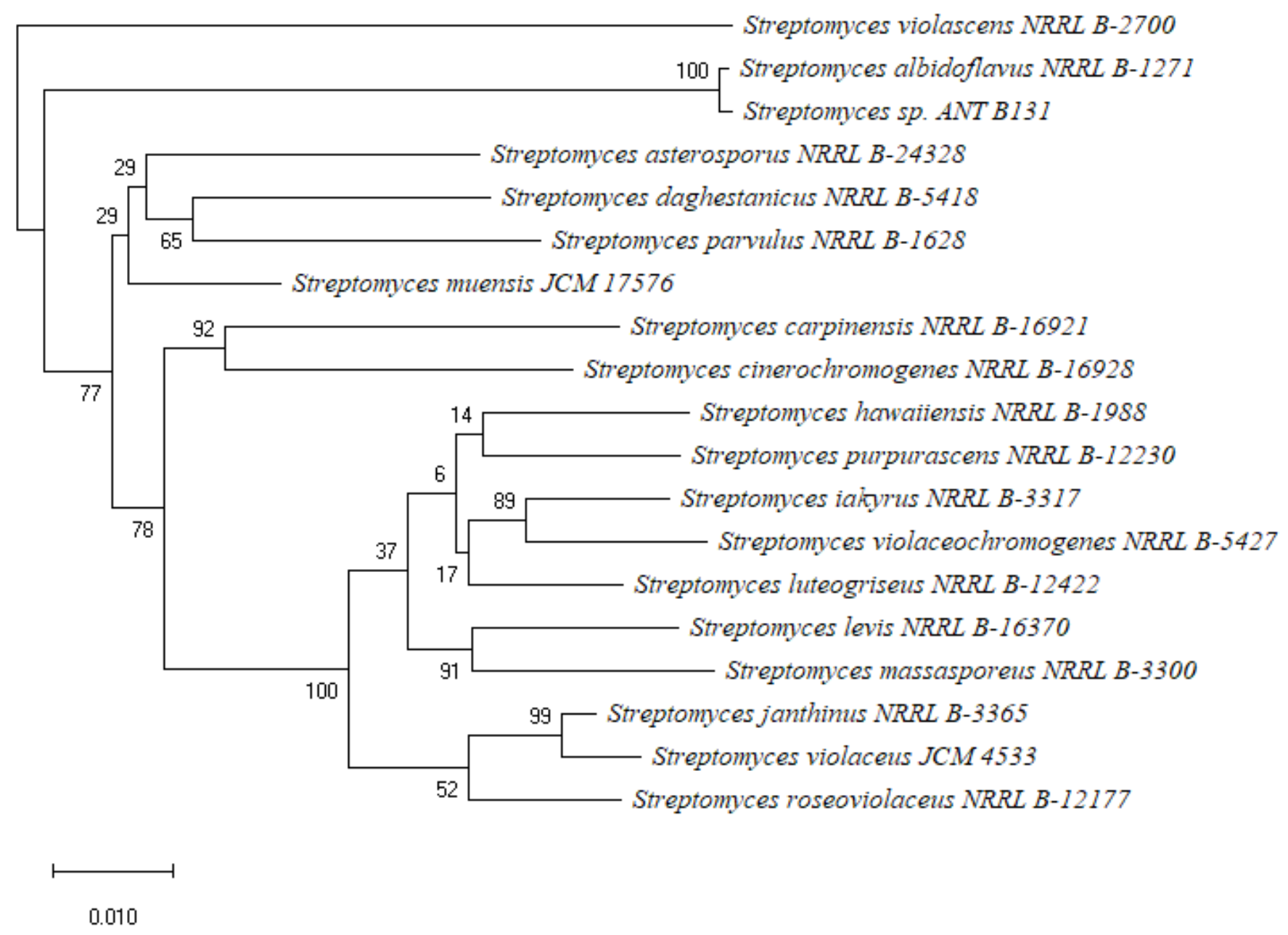

\section{Figure 1}

Multilocus Sequence Analysis (MLSA) of the genes sequence of atpD (ATP synthase F1, beta subunit), gyrB (DNA gyrase $B$ subunit), rpoB (RNA polymerase beta subunit), recA (recombinase $A$ ), and trpB (tryptophan synthetase, beta subunit A) of the ANTB_131 bacteria isolated from Antarctic and related microorganisms. Evolutionary distances were based on Kimura $2 p$ model and tree reconstruction on the neighbor-joining method. Bootstrap values (1000 repetitions, showed as \%) are listed. Scale bar represents 1 nucleotide substitution per 100 nucleotides position. 

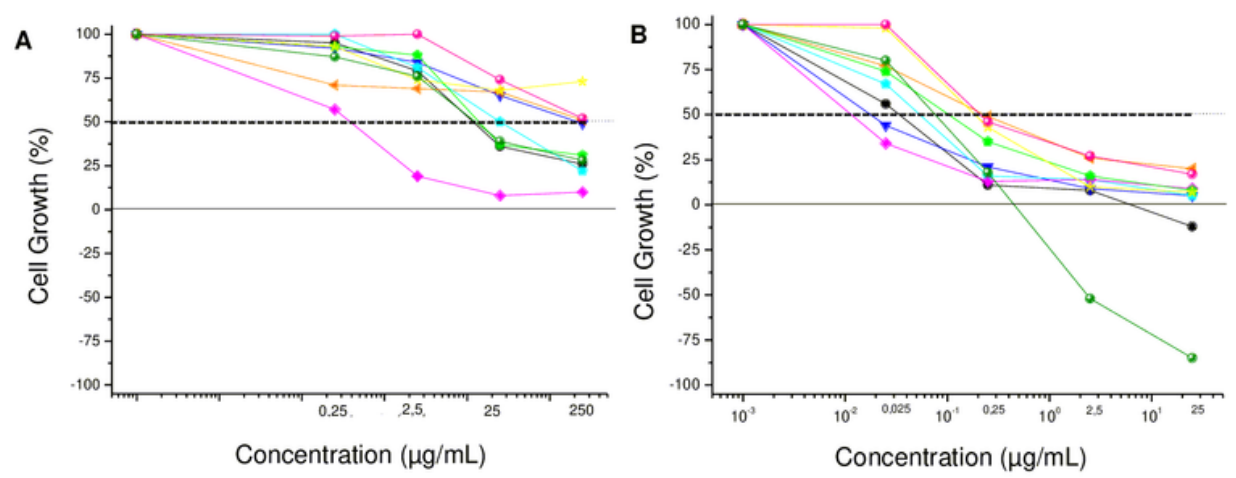

- U251 - MCF7 4 - NCl/ADR-RES - $786-0-\mathrm{NCl}-\mathrm{H} 460-\mathrm{PC}-3-\mathrm{HT} 29-\mathrm{K}-562-\mathrm{HaCaT}$

Figure 2

Antiproliferative activity in tumor cell lines. (A) Streptomyces sp. ANT_B 131 crude extract; (B) Positive control doxorubicin. 

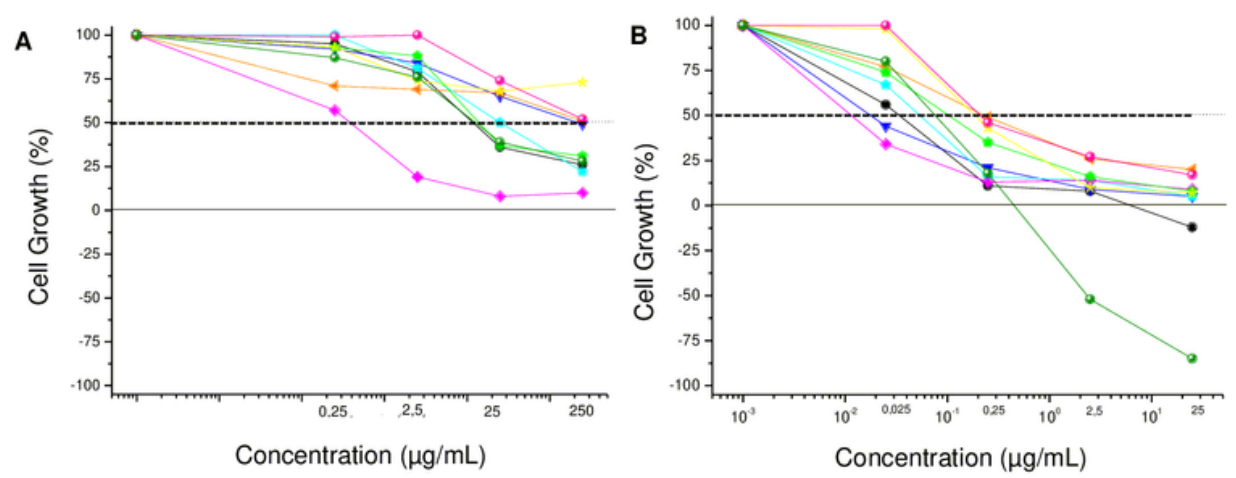

- U251 - - MCF7 4-NCl/ADR-RES - 786-0 - NCl-H460 - $-\mathrm{PC}-3-\mathrm{HT} 29-\mathrm{K}-562-\mathrm{HaCaT}$

Figure 2

Antiproliferative activity in tumor cell lines. (A) Streptomyces sp. ANT_B 131 crude extract; (B) Positive control doxorubicin. 


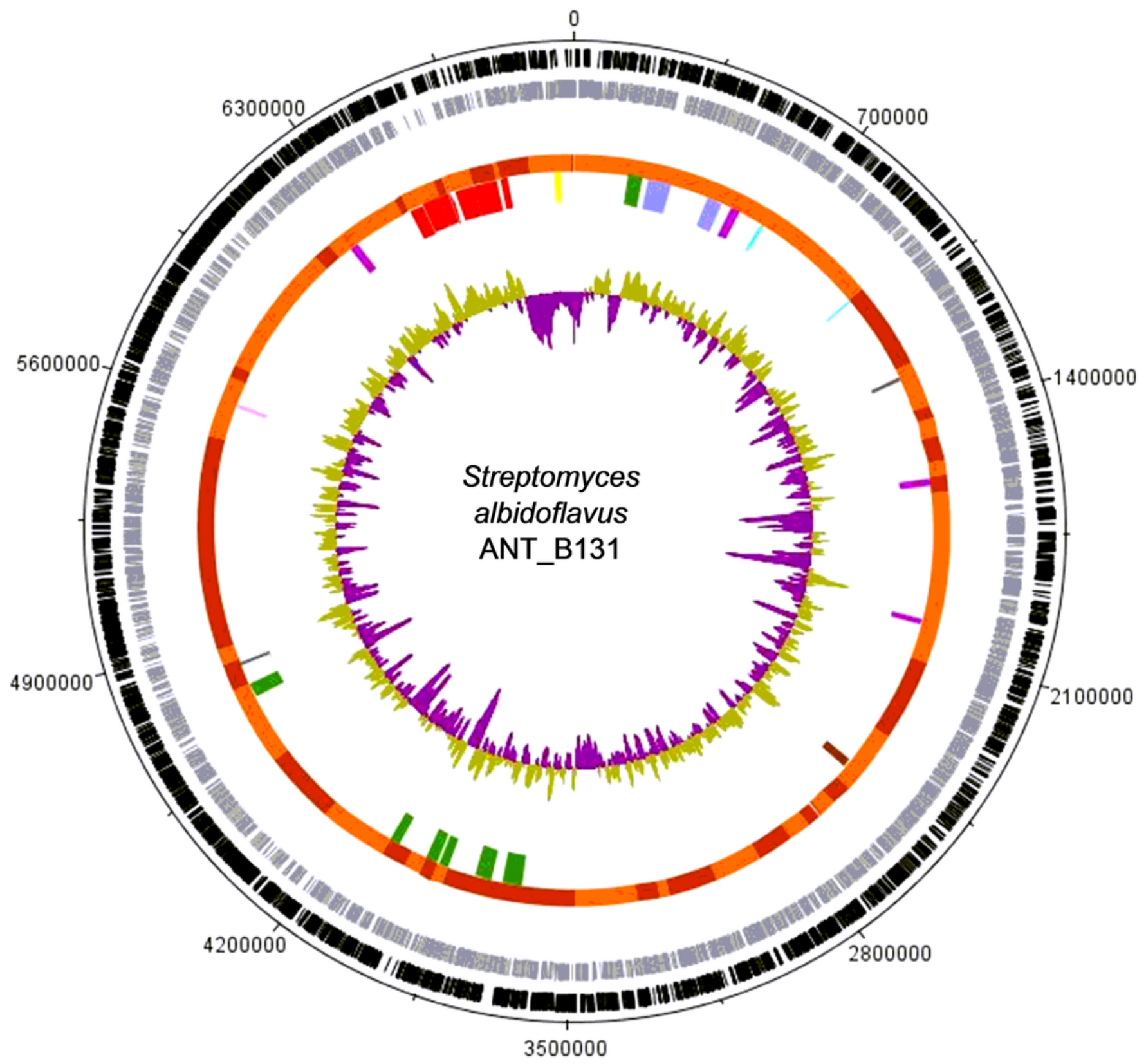
- NRPS (8) $\quad$ PKS (6)
aybrid (4)
Lassopeptide (1) Bacterio cin (2)
$\square$ Ectoine (1) $\quad$ Siderophore (2) $\square$ Terpene (4) $\quad$ Thiopeptide (1)

Figure 3

Secondary metabolite gene clusters predicted in Streptomyces albidoflavus ANT_B131 genome. From outside inward: DNA strands reverse and forward; contigs; BGCs; GC content. BGCs types are shown with different colors according to the legend. 


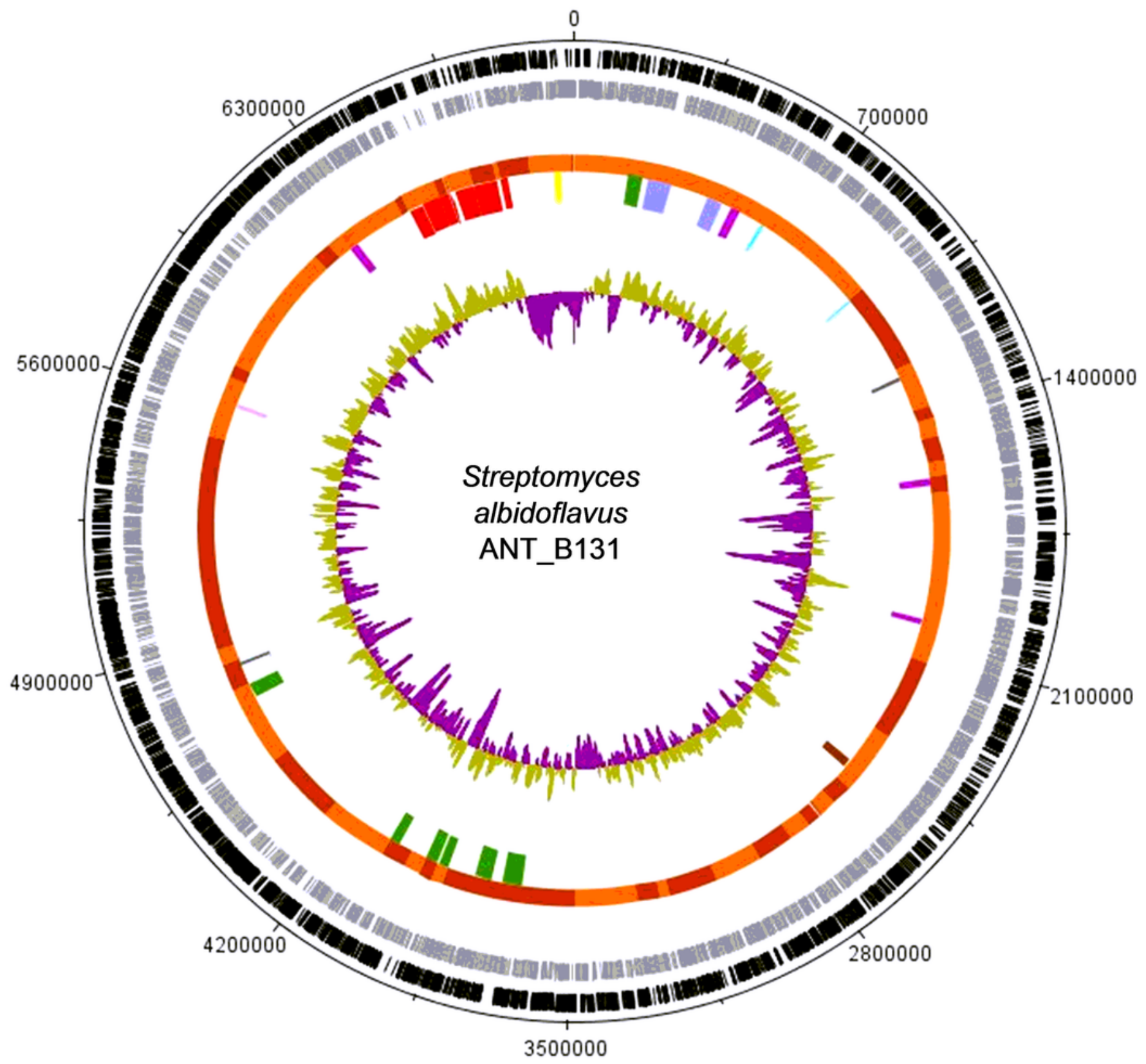
- NRPS (8) $\quad$ PKS (6)
aybrid (4)
Lassopeptide (1) Bacterio cin (2)
$\square$ Ectoine (1) $\quad$ Siderophore (2) घTerpene (4) $\quad$ Thiopeptide (1)

Figure 3

Secondary metabolite gene clusters predicted in Streptomyces albidoflavus ANT_B131 genome. From outside inward: DNA strands reverse and forward; contigs; BGCs; GC content. BGCs types are shown with different colors according to the legend. 


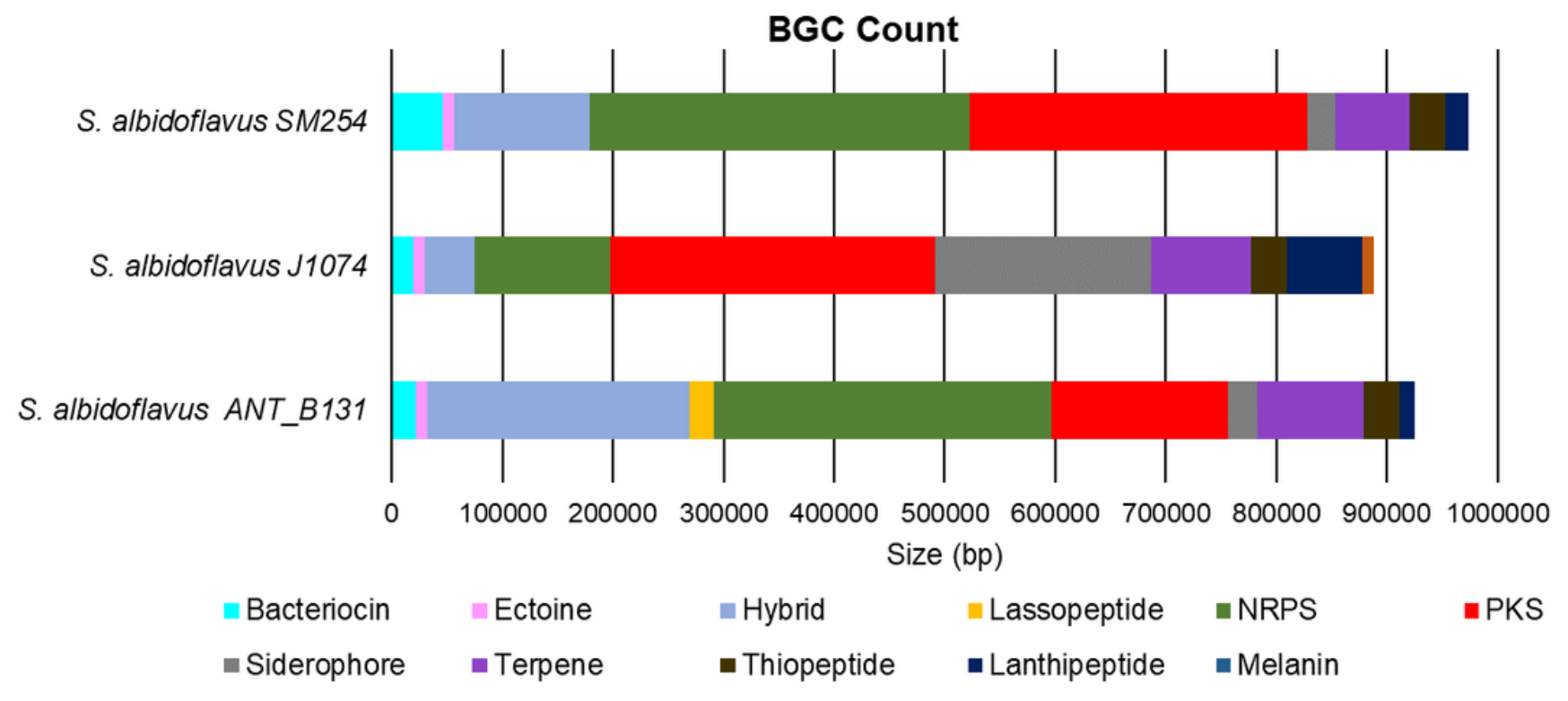

\section{Figure 4}

BGCs identified in Streptomyces albidoflavus strains genomes by antiSMASH. BGC count indicated by different colors.

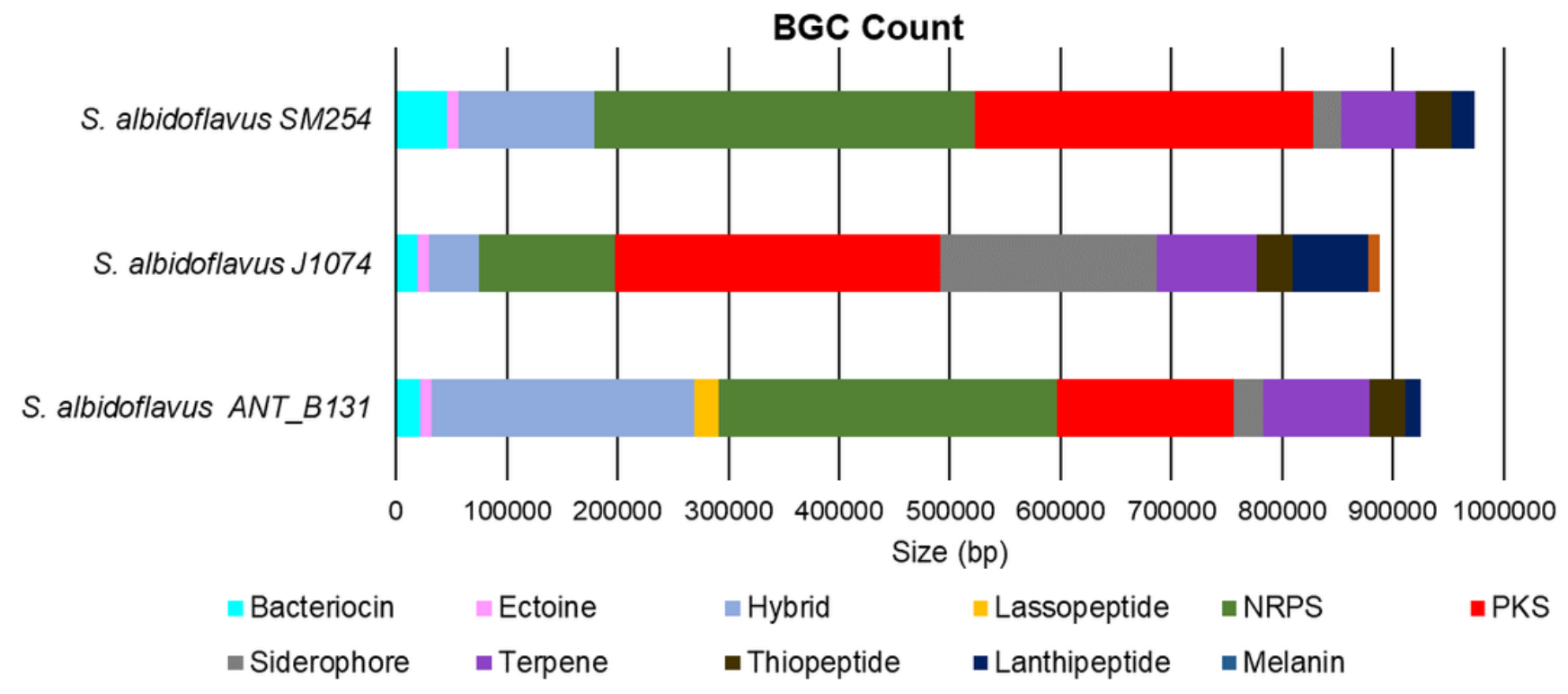

\section{Figure 4}

BGCs identified in Streptomyces albidoflavus strains genomes by antiSMASH. BGC count indicated by different colors. 
<smiles>CCC(C)NC(=O)C(NC(=O)C(C)NC(=O)C(NC(=O)C(CC)CC)NC(=O)C(NC(=O)C(CC(C)C)C(C)CC)C(C)CC)C(=O)NC(C(=O)NC(CCCCN)C(=O)NC(C(C)C)C(C)CC)C(C)CC</smiles><smiles>CCC(C)C(C)NC(=O)C(NC(=O)C(NC(=O)C(C)NC(=O)C(NC(=O)C(NC(=O)C(CC(C)C)C(C)CC)C(C)CC)C(C)CC)C(=O)NC(Cc1ccccc1)C(C)C)C(=O)NC(CCCCN)C(=O)NC(C(=O)NC(C)C(C)CC)C(C)CC</smiles>

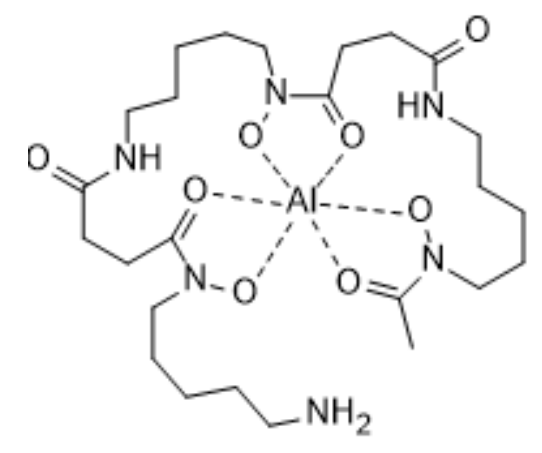

3<smiles></smiles>

\section{Figure 5}

Structures of secondary metabolites detected in the extracts of S. albidoflavus ANT_B131. Surugamide A (1), surugamide D (2), desferrioxamine B + Al (3), desferrioxamine E (4) and ectoine (5). 
<smiles>CCC(C)NC(=O)C(NC(=O)C(C)NC(=O)C(NC(=O)C(CC)CC)NC(=O)C(NC(=O)C(CC(C)C)C(C)CC)C(C)CC)C(=O)NC(C(=O)NC(CCCCN)C(=O)NC(C(C)C)C(C)CC)C(C)CC</smiles><smiles>CCC(C)C(C)NC(=O)C(NC(=O)C(NC(=O)C(C)NC(=O)C(NC(=O)C(NC(=O)C(CC(C)C)C(C)CC)C(C)CC)C(C)CC)C(=O)NC(Cc1ccccc1)C(C)C)C(=O)NC(CCCCN)C(=O)NC(C(=O)NC(C)C(C)CC)C(C)CC</smiles>

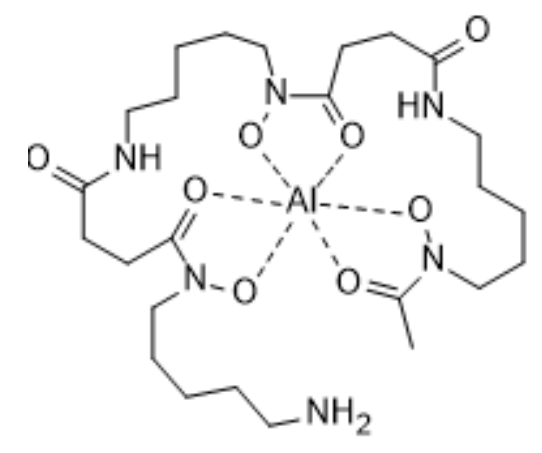

3<smiles></smiles>

\section{Figure 5}

Structures of secondary metabolites detected in the extracts of S. albidoflavus ANT_B131. Surugamide A (1), surugamide D (2), desferrioxamine B + Al (3), desferrioxamine E (4) and ectoine (5). 

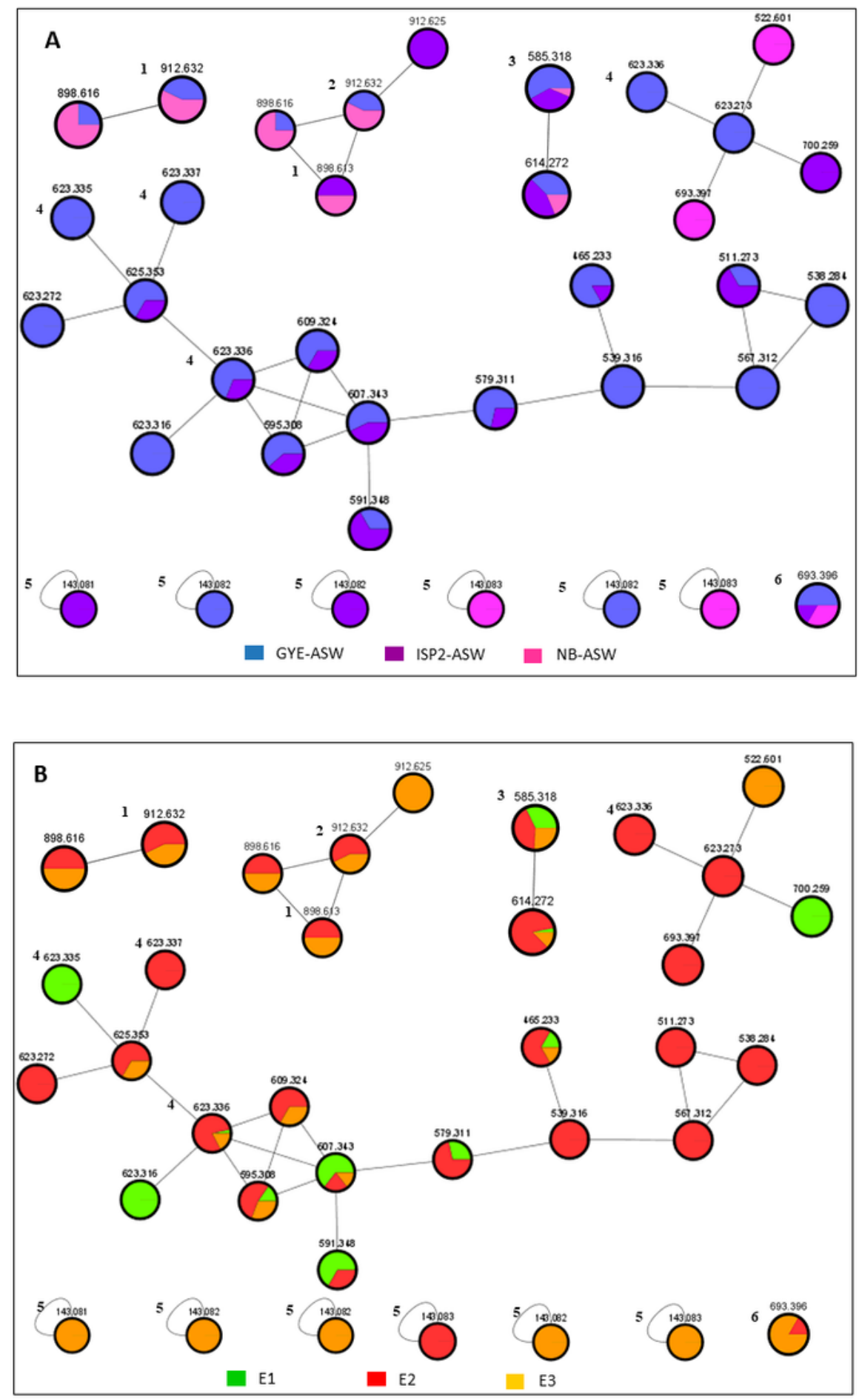

\section{Figure 6}

Streptomyces albidoflavus ANT_B131 Molecular Networking. Compounds 1 (surugamide A), 2 (surugamide D), 3 (desferrioxamine $B+A l$ ), 4 (desferrioxamine $E$ ), 5 (ectoine) and 6 (monensin) were identified in three different culture media (A) and three different types of crude extract extraction (B). E1; extraction by liquid-liquid methanol with ethyl acetate; E2; extraction of metabolites in the culture media 
using methanol; E3; extraction intracellular metabolites by methanol. Precursor mass is shown above the node.
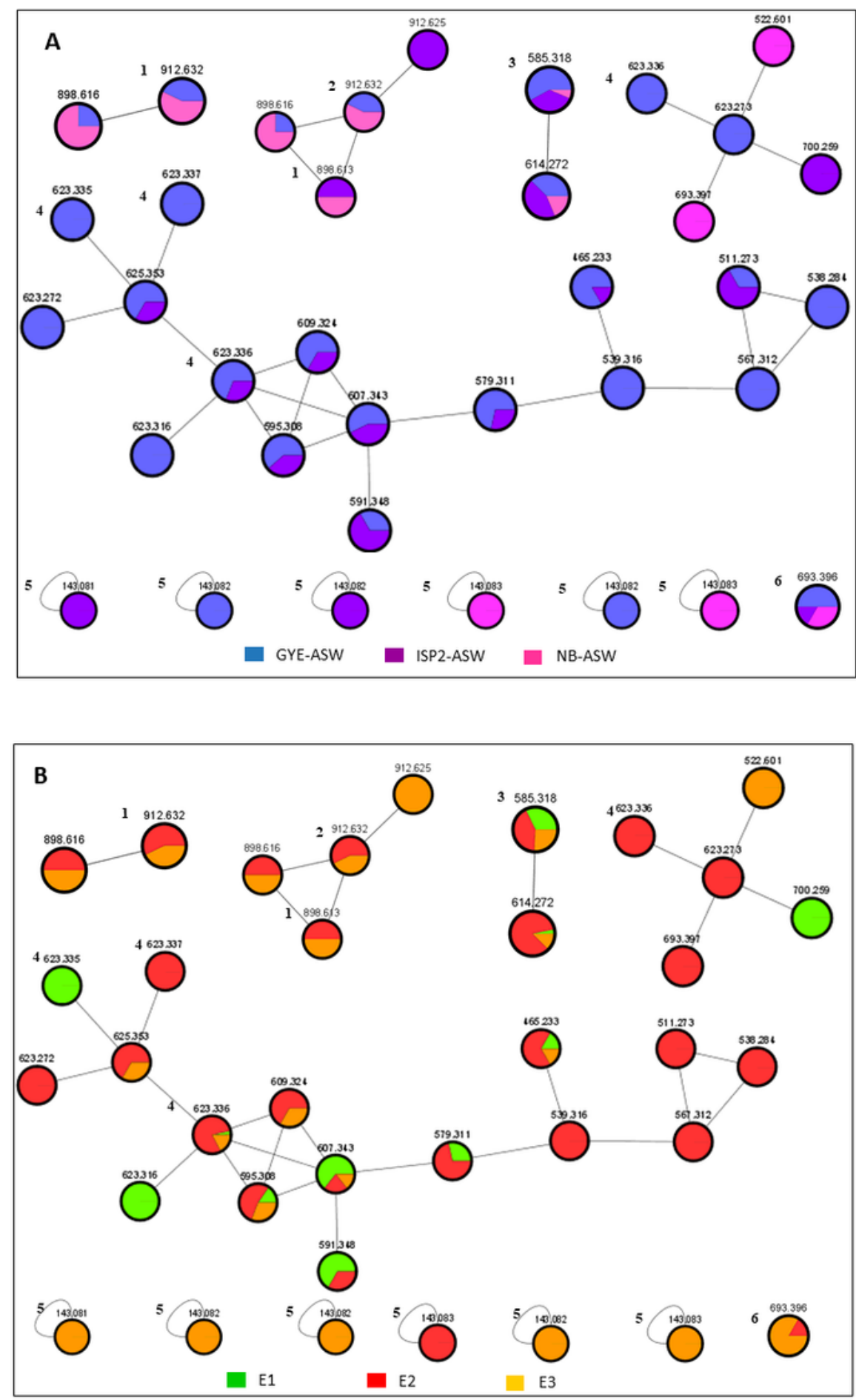

Figure 6

Streptomyces albidoflavus ANT_B131 Molecular Networking. Compounds 1 (surugamide A), 2 (surugamide D), 3 (desferrioxamine $\mathrm{B}+\mathrm{Al}$ ), 4 (desferrioxamine $\mathrm{E}$ ), 5 (ectoine) and 6 (monensin) were identified in three different culture media (A) and three different types of crude extract extraction (B). E1; 
extraction by liquid-liquid methanol with ethyl acetate; E2; extraction of metabolites in the culture media using methanol; E3; extraction intracellular metabolites by methanol. Precursor mass is shown above the node.

\section{Supplementary Files}

This is a list of supplementary files associated with this preprint. Click to download.

- SupportInformation.docx

- SupportInformation.docx 